\title{
Teaching NeuroImages: Severe myelopathy due to epidural lipomatosis
}

W. Alex Dalrymple, MD, Jason Druzgal, MD, PhD, and Guillermo Solorzano, MD, MSc

Neurology ${ }^{\circledR}$ 2018;91:e2282-e2283. doi:10.1212/WNL.0000000000006639
Correspondence

Dr. Dalrymple

Wad5g@virginia.edu

Figure 1 Sagittal T1-weighted MRI show epidural lipomatosis

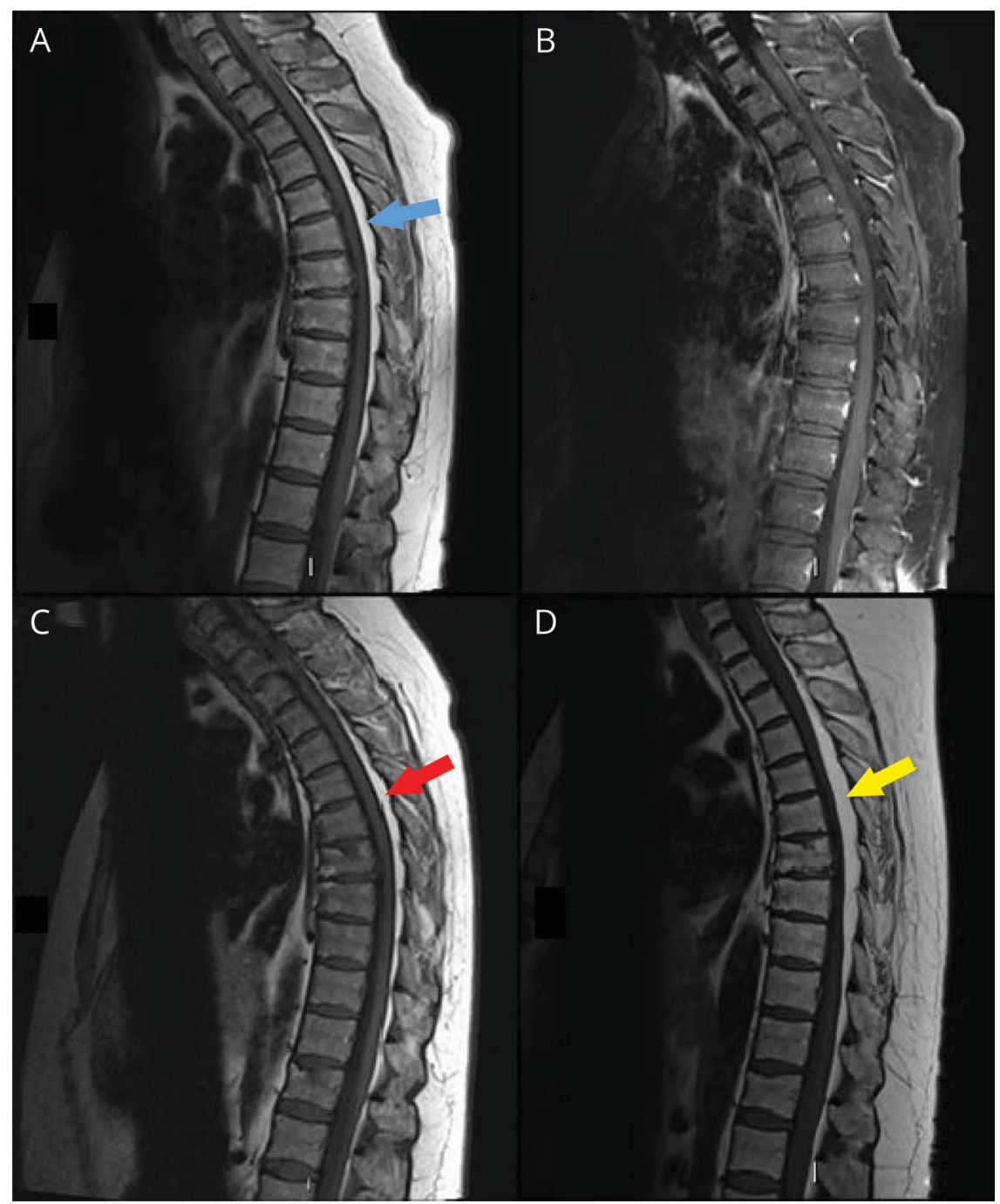

(A) Sagittal T1-weighted image of the thoracic spine from June 2016 shows increased volume of the T1-bright signal in the posterior epidural space (blue arrow) causing anterior displacement of the spinal cord. (B) Sagittal T1-weighted image of the thoracic spine with fat saturation and contrast from June 2016. As compared to the standard T1-weighted image from the same date, note the relative lack of signal intensity in the posterior epidural space. The fat saturation technique proves that the original signal abnormality is indeed fatty tissue. (C) Sagittal T1weighted image of the thoracic spine from July 2017 shows increased T1 signal in the posterior epidural space (red arrow) causing anterior displacement of the spinal cord. (D) Sagittal T1-weighted image of the thoracic spine from December 2017 shows further progression of increased T1 signal in the posterior epidural space (yellow arrow) leading to anterior displacement of the spinal cord. Note the relatively rapid accumulation of fat tissue over a few months.
A 45-year-old woman presented with 2 years of progressive bilateral leg weakness and stiffness. She had a history of severe asthma and had been on high-dose steroids for 13 years. On examination, she had a Cushingoid appearance and spastic paraparesis. Sequential MRIs of her thoracic spine demonstrated increased $\mathrm{T} 1$ signal in the epidural space consistent with epidural lipomatosis, eventually causing severe cord compression (figures 1 and 2). The epidural space
MORE ONLINE

$\rightarrow$ Teaching slides

links.lww.com/WNL/

A757

From the Department of Neurology (W.A.D., G.S.) and Department of Radiology and Medical Imaging, Division of Neuroradiology (J.D.), University of Virginia, Charlottesville. Go to Neurology.org/N for full disclosures. Funding information and disclosures deemed relevant by the authors, if any, are provided at the end of the article. 
Figure 2 Axial T1-weighted MRI show progression of epidural lipomatosis

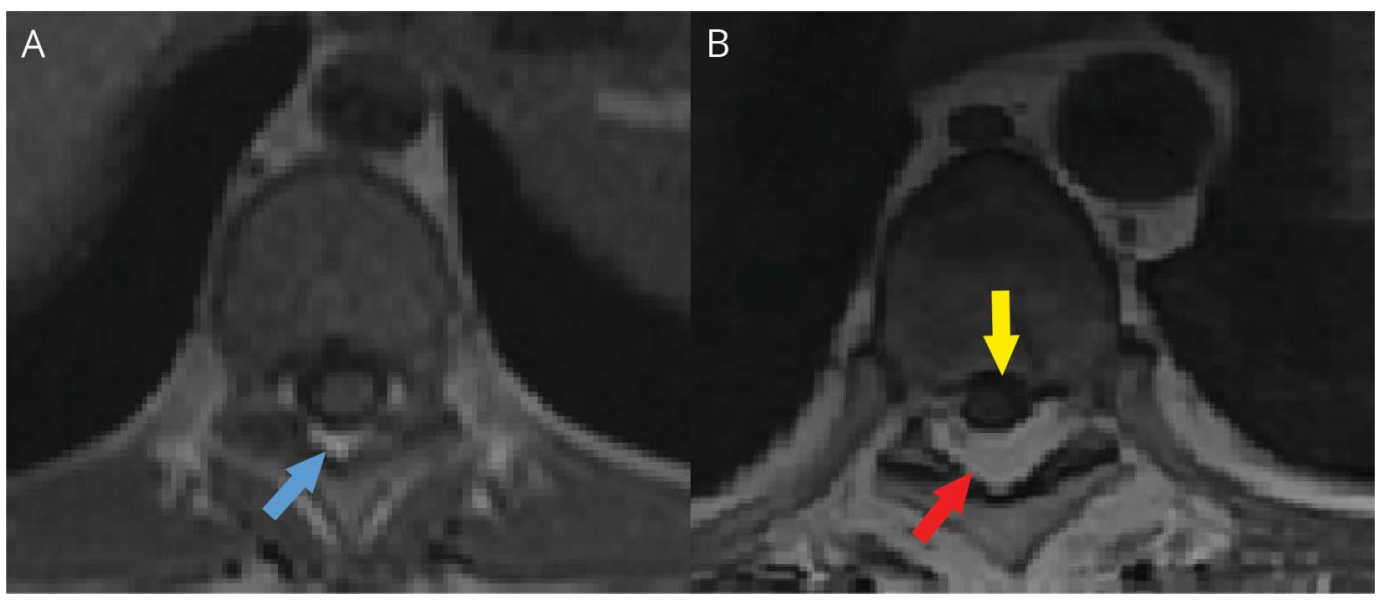

(A) Axial T1-weighted imaging at the level of the mid-thoracic cord obtained incidentally in 2009. Note the normal amount of T1-bright signal in the posterior epidural space (blue arrow). (B) Axial T1-weighted image from December 2017 at the level of the mid-thoracic spine shows fat infiltration into the epidural space (red arrow) and anterior displacement of the thoracic spinal cord (yellow arrow).

normally contains adipose tissue, but in patients who are obese or on long-term steroids, this can become pathologically enlarged. ${ }^{1}$ The treatment consists of weight loss, steroid weaning, and in severe cases, decompressive surgery. ${ }^{2}$

\section{Author contributions}

Dr. Dalrymple: design and revision of original manuscript, takes responsibility for the data, analyses, and interpretation, as well as the conduct of the case report. Dr. Druzgal: image collection, critical revision of manuscript. Dr. Solorzano: critical revision of manuscript.

\section{Study funding}

No targeted funding reported.

\section{Disclosure}

The authors report no disclosures relevant to the manuscript. Go to Neurology.org/N for full disclosures.

\section{References}

1. Fogel GR, Cunningham PY, Esses SI. Spinal epidural lipomatosis: case reports, literature review and meta-analysis. Spine J 2005;5:202-211.

2. Fassett DR, Schmidt MH. Spinal epidural lipomatosis: a review of its causes and recommendations for treatment. Neurosurg focus 2004;16:1-3. 


\section{Neurology}

\section{Teaching NeuroImages: Severe myelopathy due to epidural lipomatosis \\ W. Alex Dalrymple, Jason Druzgal and Guillermo Solorzano \\ Neurology 2018;91; $2282-\mathrm{e} 2283$ \\ DOI 10.1212/WNL.0000000000006639}

\section{This information is current as of December 10, 2018}

Updated Information \& Services

References

Subspecialty Collections

Permissions \& Licensing

Reprints including high resolution figures, can be found at: http://n.neurology.org/content/91/24/e2282.full

This article cites 2 articles, 0 of which you can access for free at: http://n.neurology.org/content/91/24/e2282.full\#ref-list-1

This article, along with others on similar topics, appears in the following collection(s):

All Spinal Cord

http://n.neurology.org/cgi/collection/all_spinal_cord MRI

http://n.neurology.org/cgi/collection/mri

Information about reproducing this article in parts (figures,tables) or in its entirety can be found online at:

http://www.neurology.org/about/about_the_journal\#permissions

Information about ordering reprints can be found online:

http://n.neurology.org/subscribers/advertise

Neurology ${ }^{\circledR}$ is the official journal of the American Academy of Neurology. Published continuously since 1951, it is now a weekly with 48 issues per year. Copyright @ 2018 American Academy of Neurology. All rights reserved. Print ISSN: 0028-3878. Online ISSN: 1526-632X.

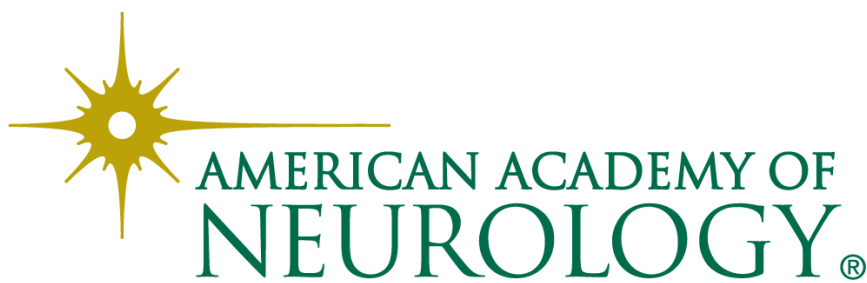

